


\title{
Research, Protection, and Re-Use Possibilities \\ for Post-War Industrial Heritage in the Czech \\ Republic - Current Research and Efforts \\ towards Protection
}

Výzkum, ochrana a nové možné využití poválečného průmyslového dědictví v České republice - současné výzkumy a snahy o diskuzi k zachování tohoto kulturního dědictví

\author{
Lenka Popelová, Tomáš Šenberger
}

Z hlediska typologického vývoje průmyslových staveb z období druhé poloviny 2o. století jsou v Česku některé podniky již zcela nefunkční, jiné stále funkční, ale s ohledem na připravovanou „průmyslovou revoluci 4.0“ již z podstaty propagované změny všechny potenciálně ohroženy. Vnímáme-li průmyslové dědictví jako součást kulturního dědictví, a obecně architektonické památky z druhé poloviny 20. století již nikdo nezpochybňuje jako jeho součást, je načase se zabývat i hodnocením průmyslových budov z tohoto období. Jejich kvality, založené na velmi koncepčním přistupu, při kterém byly zohledněny jak potřeby nových výrobních technologií, možnosti neobvyklých konstrukcí, ale i snahy o kvalitní architektonická řešení a i první náznaky ochrany životního prostředí, si nepochybně zaslouží naši aktuální pozornost. Nejde samozřejmě o velké počty návrhů na památkovou ochranu, ale o seriózní zhodnocení kvalit vybraného vzorku dle sledovaných kritérií a zvolení několika výjimečných zástupců směrovaných k zápisu do seznamu nemovitých kulturních památek.

Článek se zabývá současnými snahami o mapování průmyslových památek (chápaných dle Charty TICCIH v nejširším slova smyslu). Jsou to aktivity pracovní skupiny pro architekturu druhé poloviny 20. století při ČNK ICOMOS, dále projekt NAKI II Prezentace hodnot architektury šedesátých a sedmdesátých let, který v letech 2016 - 2020 inicioval Národní památkový ústav ČR (2016 - 2020), a výzkumy probíhající aktuálně na katedře architektury FSv ČVUT v Praze, zejména v rámci doktorských studijních programů a oborů - Průmyslové dědictví a Trvale udržitelný rozvoj a průmyslové dědictví.

Z výzkumu je zřejmé, že při hodnocení je nutné vycházet $\mathrm{z}$ definované strukturalizace typologických druhů, které jsou až ve druhém plánu spojeny s otázkou architektonického výrazu. Jedná se ale o hledisko, které je blíže původnímu architektonickému uvažování o navrhování průmyslových staveb než hledisko estetické, které může v oblasti památkové péče převažovat. $\mathrm{V}$ tomto bodě výzkum navazuje na zmíněné metodické hodnocení průmyslového dědictví zpracované Milošem Matějem a Michaelou Ryškovou, v obecné rovině je pak argument pro ochranu možné podpořit publikovanou metodikou v rámci zmiňovaného projektu NAKI II zabývajícího se architekturou šedesátých a sedmdesátých let 2o. století.

Jako významná novinka byl na počátku šedesátých let zaveden do průmyslové typologie nový pojem „generální plán výrobního závodu“ („generel“), který syntetizoval požadavky na výstavbu průmyslového závodu a umíst’oval a koordinoval veškeré objekty, inženýrské sítě, komunikace a zeleň na pozemku určeném k výstavbě. Po vzoru realizací na Západě byla jako jedna z hlavních metod návrhu propagována metoda zón a sekcí základní princip tvorby organizovaného území, členěného vzájemně kolmými pásmy. Pragmatické snahy o zmenšení rozsahu zabírané zemědělské půdy, o racionalizaci a zkrácení provozních vazeb, o hledání úspor nárokovaných energií nakonec vyústily v zásadní typologické inovace, které přinesly i pozitivní dopady na zlepšení pracovního prostředí i na výsledná architektonická řešení. Při návrhu univerzálních, víceúčelových závodů se nové tendence promítly především do konceptu továren, koncentrovaných do jediného stavebního objektu - „monobloku“, vývoj probíhal i v oblasti jednoúčelových, speciálních staveb, a to formou studií, soutěží i realizací, jejichž přehled článek shrnuje.

Průmyslové stavby z druhé poloviny 2o. století, často architektonicky, typologicky i technologicky velmi zajímavé a reprezentující rozvoj techniky a dobové průmyslové úsilí, stojí stále na okraji odborného zájmu a téměř se nedostávají do hledáčku možností nového využití. I na tyto možnosti článek upozorňuje. 

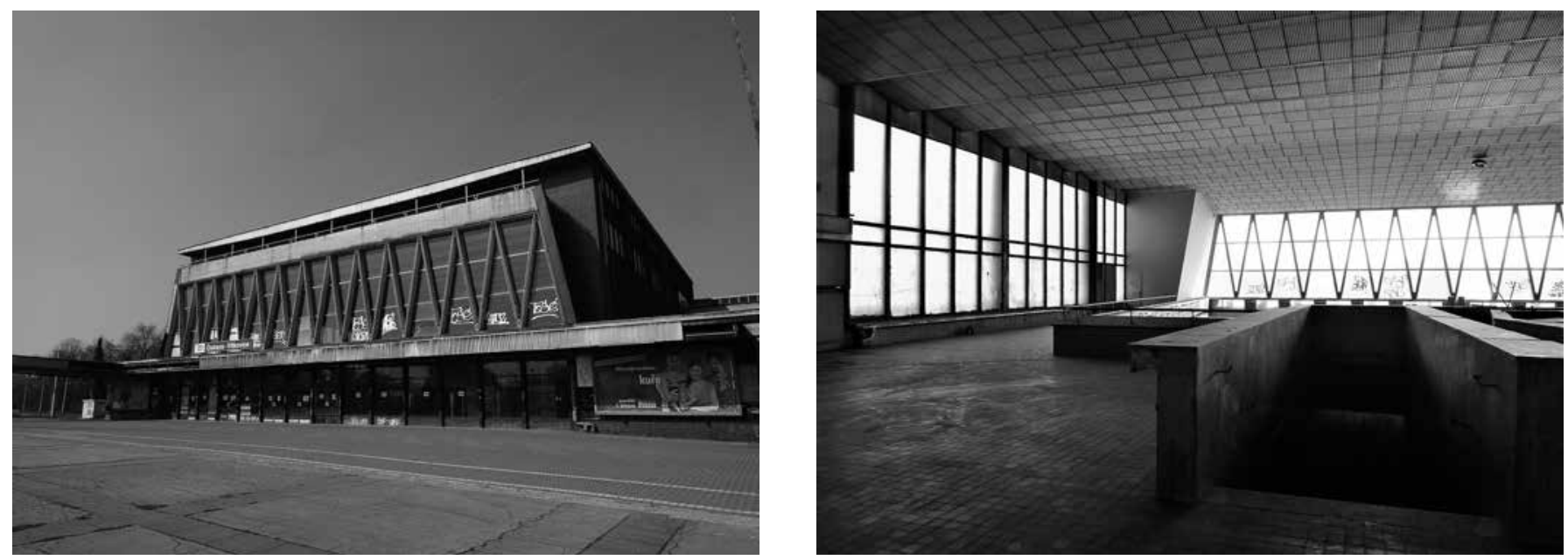

CONFIRMED AS CULTURAL HERITAGE SINCE 2020 - THE DISPATCHING BUILDING OF THE OSTRAVA-VÍTKOVICE RAIL STATION. THE BUILDING AND ITS INTERIOR, UNFORTUNATELY HARMED BY THE REDUCTION IN ITS USE. JOSEF DANDA, 1963 - 1967. OD ROKU 2020 JIŽ DEFINITIVNĚ KULTURNII PAMÁTKA - VÝPRAVNÍ BUDOVA ŽELEZNIČNI STANICE OSTRAVA-VÍTKOVICE. VÝPRAVNI BUDOVA A INTERIÉR, BOHUŽEL POSTIŽENÝ UTLUMENÍM SVÉ FUNKCE. JOSEF DANDA, 1963 - 1967. Photo Foto: Lenka Popelová, 2017

THE LANDMARKED RAIL STATION IN DUCHCOV. A HIGHLY AUTHENTIC STRUCTURE, UNFORTUNATELY HARMED BY THE REDUCTION IN ITS USE. JIŘÍ HYLIŠ, 1962 - 1969.

KULTURNÍ PAMÁTKA NÁDRAŽí DUCHCOV. VELMI AUTENTICKÝ OBJEKT, BOHUŽEL POSTIŽENÝ UTLUMENÍM SVÉ FUNKCE. JIŘÍ HYLIŠ, $1962-1969$.

Photo Foto: Lenka Popelová, 2017

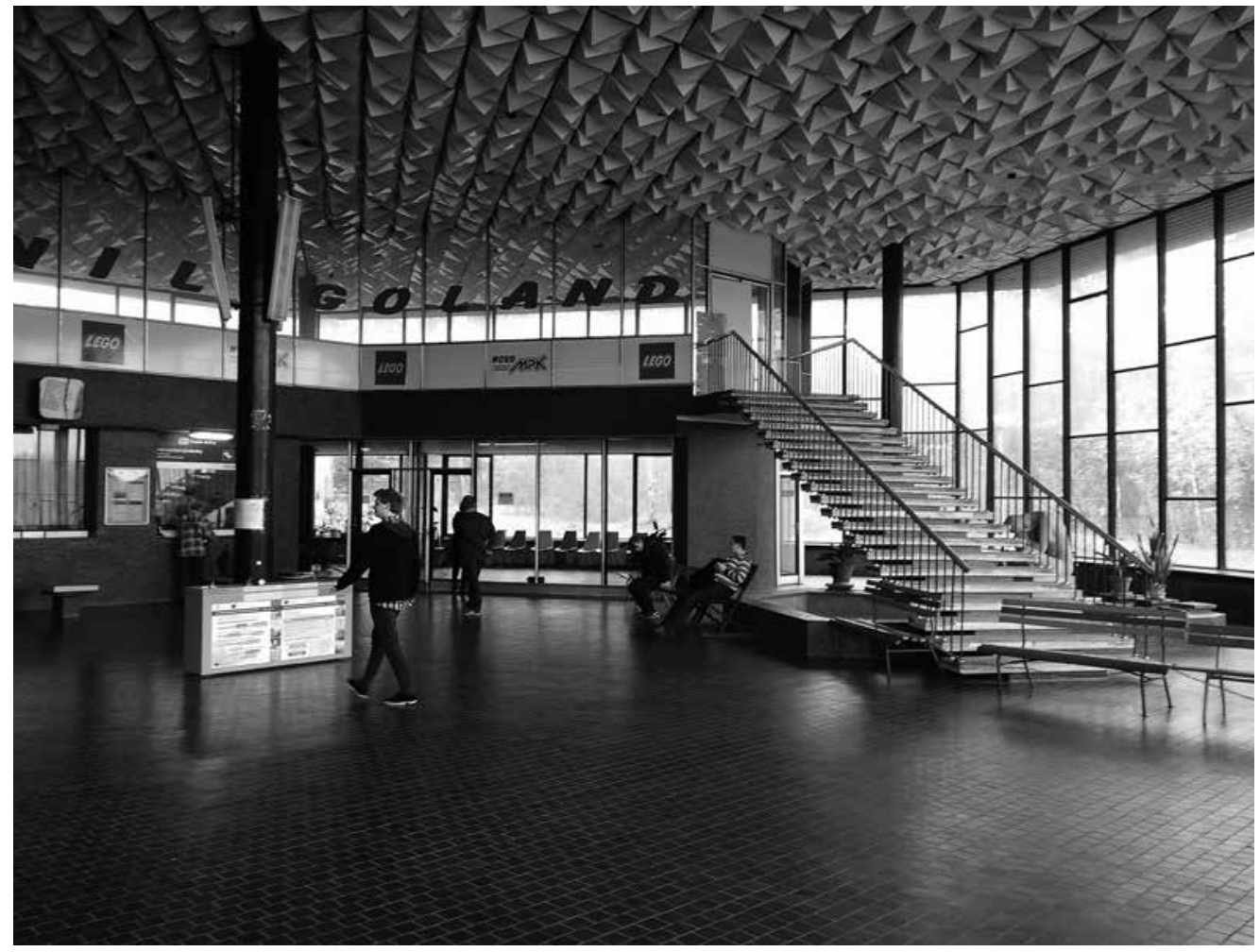

Industrial architecture built during the second half of the 2oth century has already acquired its place in the professional debate on industrial heritage research and protection. However, industrial buildings from the 1950s through the 1980s, though often of notable architectural, typological and technological interest, representing the development of productive-technology efforts of that era, still occupy only the fringe of professional interest.

However, ongoing research on the architectural heritage of this period shows that the topic is extremely vital and affects the overall position of research and protection of postwar architecture in the Czech Republic. In terms of identification and evaluation of postwar architecture, there is a consensus on general and specific values, as recently defined in the Conservation Methodology for the Buildings of the Second Half of the 2oth Century ${ }^{1}$, published in $202 \mathrm{O}$ as an outcome of the NAK II grant dealing with the conservation of the 1960 s and 1970 buildings. ${ }^{2}$ This document focuses the evaluation criteria on the development of form and aesthetics, construction, structural materials, and also artistic details in architecture. Although the methodology neglects the specifics of industrial buildings, these criteria can be effectively utilized in the evaluation if there is a will (unfortunately, 
the Evaluation and Protection of Industrial Heritage from the Perspective of Heritage Management ${ }^{3}$ did not deal with them either).

We continue to notice a certain unjustified bias among the professional public caused by the socialist-construction context of the construction of this era. This problem is specific to industrial buildings because of their persistent non-acceptance within the commonly evaluated typologies.

The status of postwar industrial heritage ${ }^{4}$ is distinctive not only for its unique, socialist state-controlled development, but also for the issue of its destruction. It is worth noting that after the fall of socialism in 1989, the ongoing economic and social transformation, as well as generally significant changes in typological and technological-production solutions, have all contributed to the present situation in which a number of industrial, production-technical, and transportation buildings in the Czech Republic from the second half of the 2oth century are currently at risk of losing their function, of failure of sufficient maintenance, as well as demolitions, several of which we recently witnessed. On the other hand, further plants are still open and running, in which case the early recognition of their value may enable the prevention of their demise. So, the current task is to formulate how this layer of industrial heritage can be protected and what problems can be encountered in efforts to reuse it.

The text below summarizes current efforts toward inventory work, which the authors deal with along multiple lines. It also addresses an essential issue of interpreting general characteristics, without which it is impossible to understand and further interpret the inventories. And finally, it discusses in more detail the issue of the importance of architectural competitions in design practice. The results should help in the discussion on the recognition, protection, and/or re-use of these buildings.

\section{Inventory Work}

An independent group of young researchers associated with the Working Group for Post-War Architecture, a body affiliated with the ICOMOS Czech Committee, joined the wider debate on the protection of postwar architectural heritage and at the end of 2017 published a list of the most prominent architectural works of the second half of the 2oth century, as we felt that there was a lack of information. ${ }^{5}$

The list includes cultural monuments, buildings considered for protection, damaging reconstructions, or demolition. Following the advice of Prof. Rostislav Švácha, it was ranked by typological affiliation and included, among criteria, several industrial buildings. It showed the presence of approximately $14^{6}$ monitored industrial cultural monuments in the Czech Republic (mainly mining towers and mining equipment, water works, in rare instances railway buildings). Consequently, the selection of monuments is to date both incomplete and unrepresentative.

The inventory also included demolitions, which continue to take place at a great pace until today: Nosek Mine in Tuchlovice (Otakar Štěpánek, Arnošt Přikryl, 1946 - 1947), ČKD Shipyard in Prague-Libeň, Jaroslav Fragner, 1947), Tušimice I Power Plant, Energoprojekt Prague (Karel Šlapák, Vladimír Vízek, Zdeněk Vávra, Arnošt Hauer, Vladimír Zdeněk, Jaroslav Kubát, 1961 - 1964), bus station in the "Rotunda" in Haviŕov, heating plant at the Invalidovna housing estate "Mazutka" in Prague-Karlín (Jan Zelený, František Bäumelt, 1964 - 1966), spindleless spinning mill in Ústí nad Orlicí (Zdeněk Plesník, 1966), Transgas complex in Prague-Vinohrady, Vinohradská (Ivo Loos, Jindřich Malátek, Václav Aulický, Jiří Eisenreich, 1966 - 1978). Unfortunately, the list is still expanding,? revealing the loss of typologically, architecturally, and structurally interesting works, significant representatives of their time. A document entitled Ideas for Cultural Monuments was later sent to the Ministry of Culture. ${ }^{8}$ This document proposes 74 buildings of all typologies for protection and also 8 industrial buildings (see the list). The buildings we monitored included e.g., Dairy and milk drying plant in Strakonice (Josef Havlíček, Josef Hrubý and František Kerhart, technology by Julius Šmerák, 1949 - 1951), Klíčov public transport garages in Prague (Josef Zeman, 1965 1973), Railway station in Bystřice pod Hostýnem, Anton Dachler, Ivo Řehoř (1970 - start of operation), Bytex textile works in Náměšt' nad Oslavou (Zdeněk Plesník, Ludvík Jungwirth, 1974 - 1977), Transit Telephone Exchange in Hradec Králové (Václav Aulický, Jiří Eisenreich, Jindřich Malátek, Jaromíra Eisemannová, 1978 - 1984), Nusle Bridge and Vyšehrad Metro Station (Stanislav Hubička et al., 1967 - 1973), Dívčí Hrady Water Tower, Prague (Karel Hubáček, Zdeněk Patrman, 1974), Žižkov TV Tower (Václav Aulický et al., 1985 - 1992). The buildings on this list were selected because they appear interesting within the entire range of postwar architecture in terms of their typology, design, and structure; in 
THE FORMER TRANSGAS BUILDING: UNDER DEMOLITION AND DURING CONSTRUCTION IN A SLIDE BY IVO LOOS. IVO LOOS, JINDŘICH MALÁTEK, VÁCLAV AULICKÝ, JIŘÍ EISENREICH, 1966 - 1978.

OBJEKT BÝVALÉHO TRANSGASU VDEMOLICI A DIAPOZITIVIVA LOOSE Z VÝSTAVBY. IVO LOOS, JINDŘICH MALÁTEK, VÁCLAV AULICKÝ, JIŘÍ EISENREICH $1966-1978$.

Photo Foto: Lenka Popelová, 2019 a soukromý archiv Lucie Loosové
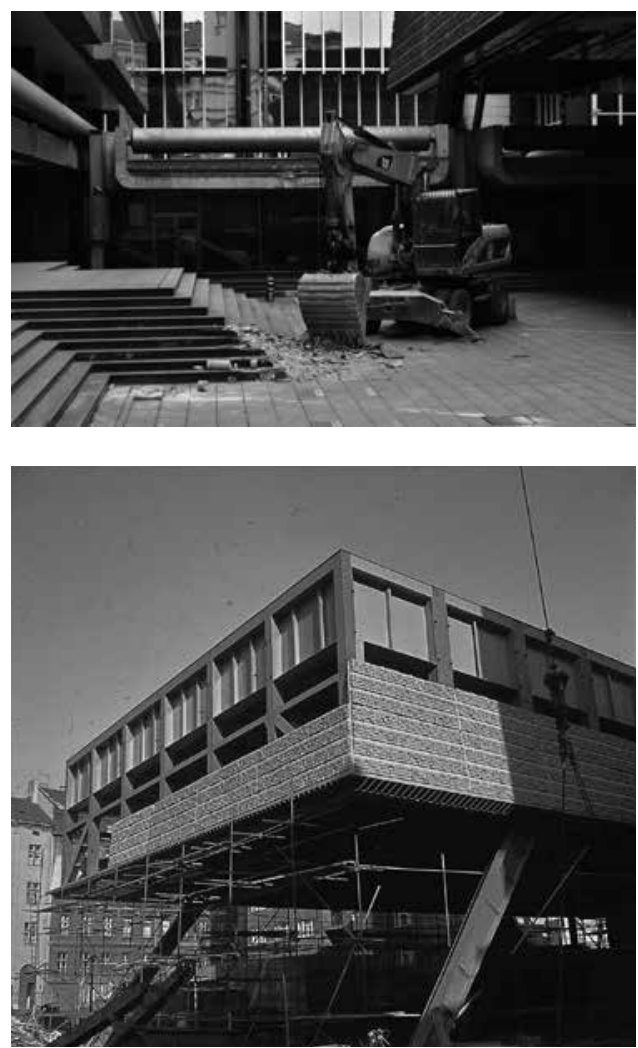

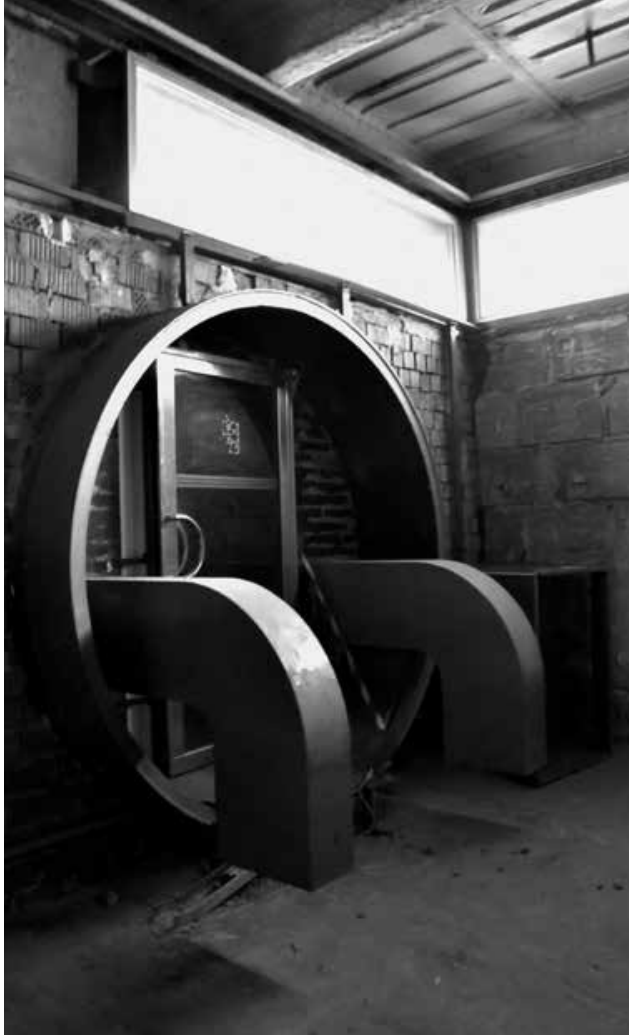

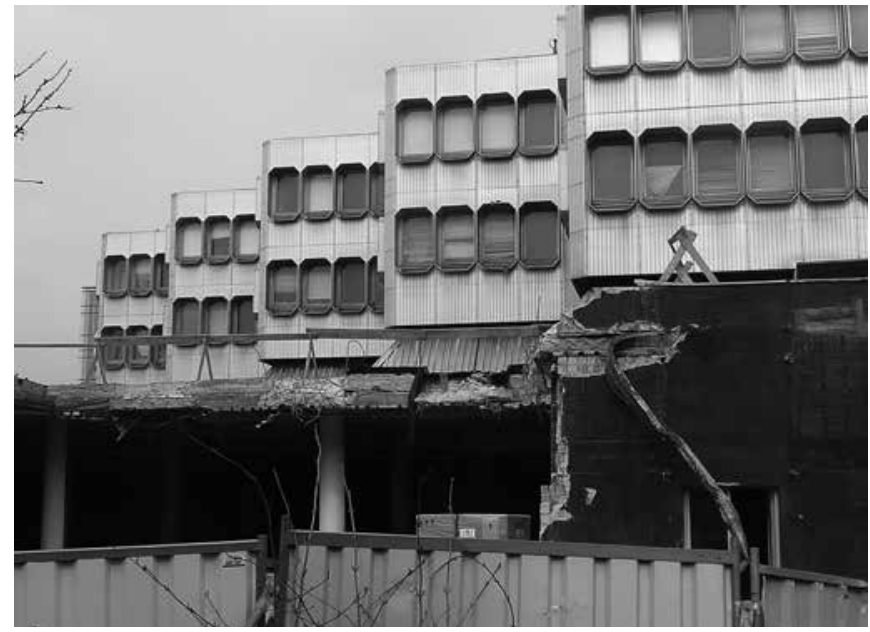

THE AUTOMATIC TELEPHONE

EXCHANGE, PRAGUE-DEJVICE,

UNDER DEMOLITION. JINDŘICH

MALÁTEK, JIŘí EISENREICH,

VÁCLAV AULICKÝ AND JAROMÍRA

EISEMANNOVÁ, 1975 - 1982.

AUTOMATICKÁ TELEFONNI

ÚSTŘEDNA DEJVICE V DEMOLICI.

JINDŘICH MALÁTEK, JIŘÍ

EISENREICH, VÁCLAV AULICKY

A JAROMÍRA EISEMANNOVÁ

$1975-1982$.

Photo Foto: Lenka Popelová, 2017

other words, no emphasis was put on the representation of individual sectors, as this was perceived as a detail.

In the latest and most extensive research into the architecture of the 1960s and 1970s, which was carried out as part of the National and Cultural Identity project (NAKI II) entitled Presentation of Values of the 1960 and 1970 as Part of the National and Cultural Identity of the Czech Republic,' and implemented in 2016 - 2020 by the Department of Architecture, Faculty of Civil Engineering, CTU in Prague (hereinafter as CTU) and the National Heritage Institute, some of the industrial buildings appeared in the inventory. ${ }^{10}$ Although this heterogeneous sample of industrial heritage was not further analysed, it was important because heritage protection at this point finally started to deal with this issue, and the monitored buildings are now in a position for comparison with other construction. The actual presence of the mentioned structures in the researched sample provides an argument for the process of their future preservation. The total of 624 entries in the inventory 

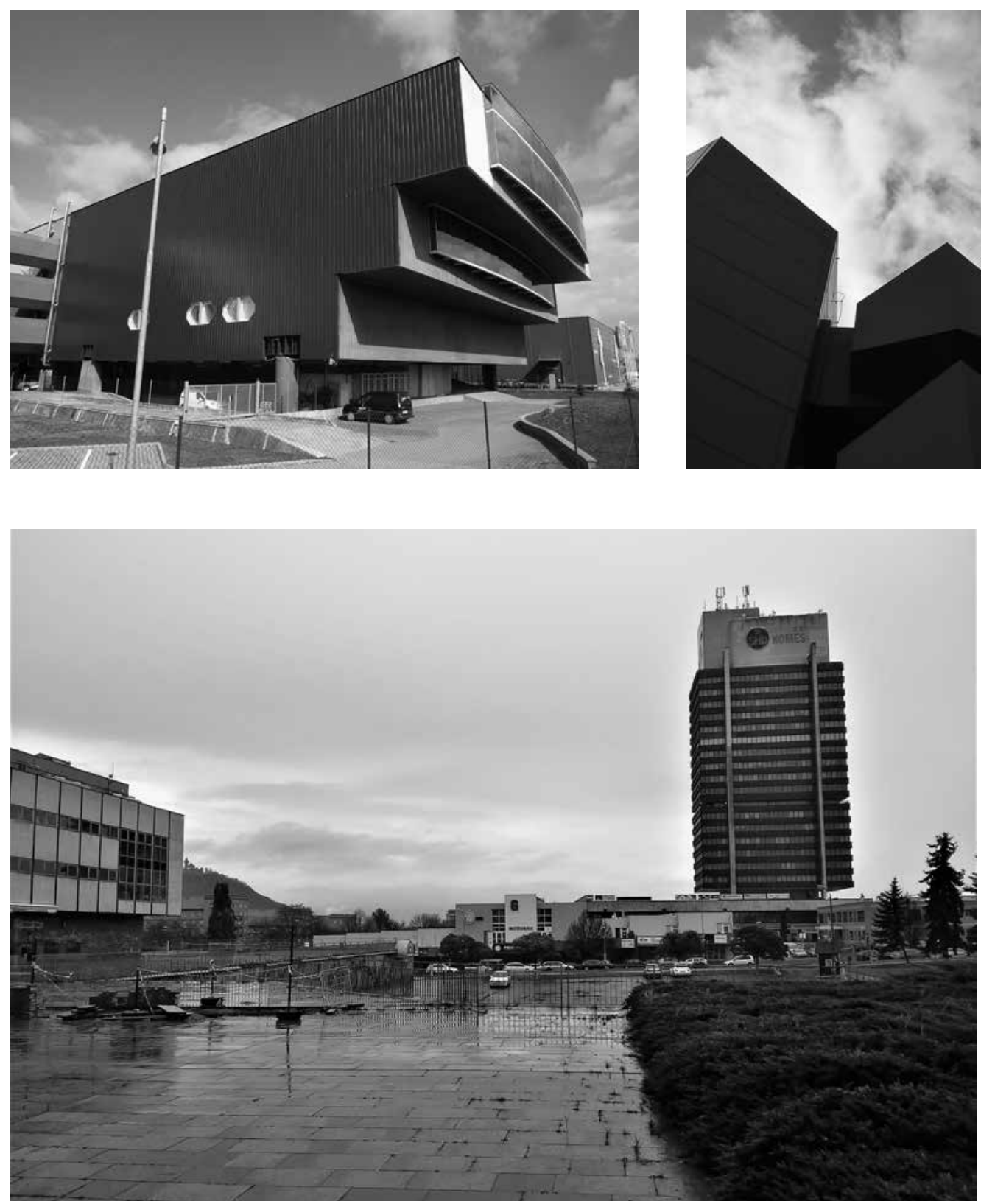

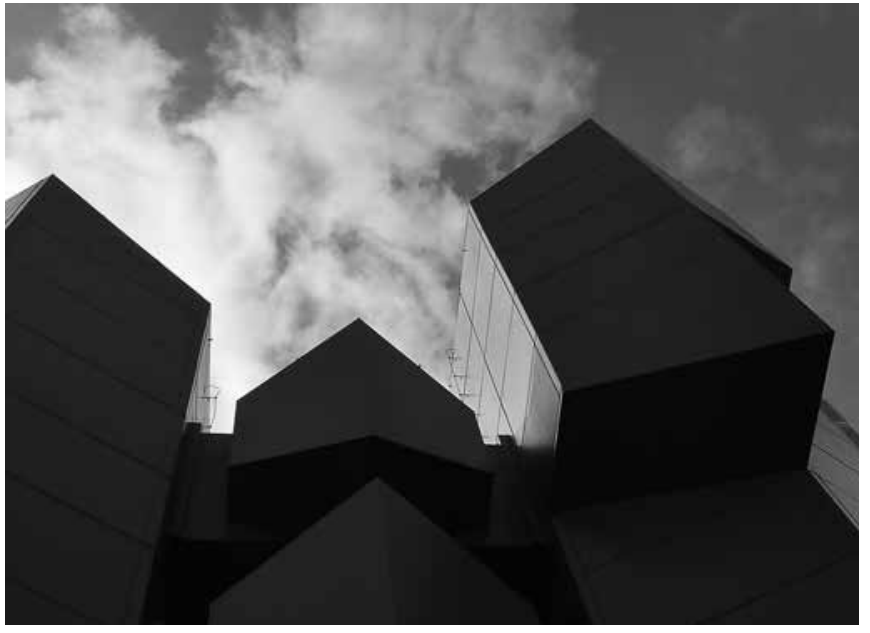

THE TRANSIT TELEPHONE EXCHANGE, HRADEC KRÁLOVÉ. PARTIAL ADAPTIVE REUSE FOR OFFICES. VÁCLAV AULICKÝ, JIŘÍ EISENREICH, JINDŘICH MALÁTEK JAROMÍRA EISEMANNOVÁ, $1978-1984$.

TRANZITNÍ TELEFONNÍ ÚSTŘEDNA VHRADCI KRÁLOVÉ. ČÁSTEČNĚ NOVÉ VYUŽITÍ PRO ADMINISTRATIVU. VÁCLAV AULICKÝ, JIŘÍ EISENREICH, JINDŘICH MALÁTEK, JAROMÍRA EISEMANNOVÁ, 1978 - 1984.

Photo Foto: Lenka Popelová, 2019
THE BUILDING OF THE GENERAL DIRECTORATE OF THE NORTH BOHEMIAN BROWN-COAL MINES IN THE WIDER CONTEXT OF THE CITY OF MOST. VÁCLAV KREJČí JIŘí FOJT, MÍŤA HEJDUK, 1970, 1977-1984. IN THIS INSTANCE, FULL HERITAGE PROTECTION FOR THE ENTIRE NEW CENTRE IS BEING CONSIDERED.

BUDOVA GENERÁLNÍHO ŘEDITELSTVÍ SEVEROČESKÝCH HNĚDOUHELNÝCH REVÍRŮ VŠIRŠÍM KONTEXTU MESTA MOST. VACLAV KREJČÍ, JIŘÍ FOJT, MÍŤA HEJDUK, 1970, 1977 - 1984. V TOMTO PŘíPADĚ

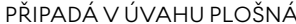
OCHRANA CELÉHO NOVÉHO CENTRA.

Photo Foto: Jiří Moos, 2017 thus included different structures, according to the TICCIH definition, connected in any aspect with the phenomenon of industrialisation. What has become evident is the following: the most notable instances were the custom-designed administrative buildings which served many socialist factories for representation - used to distinguish themselves through interesting designs (e.g., the building of the headquarters of the North Bohemian Brown Coal Mines in Most, as well as the State Textile Research Institute in Liberec, or the headquarters of Vitkovice Ironworks in Ostrava and the foreign trade firm PZO Jablonex in Jablonec nad Nisou). Some attention was also paid to mapping of telecommunication premises (now at high risk of demolition), bridges, railway stations, and water management structures, selected power plants (Dukovany nuclear power plant), glassworks (Jablonec nad Nisou, New Kavalier glasswork plant in Sázava, Crystalex in Nový Bor), Plastimat in Liberec, the already demolished mazut heating plant in the Invalidovna housing estate in Prague.

As a side note, we selected two structures from the sample to illustrate our approaches towards the industrial heritage of the era. The first one was a case study of the late modernist (or Brussels Style) Ostrava-Vítkovice railway station, ${ }^{11}$ which was at risk of demolition and was eventually declared as a cultural monument. In this book, the FCE described possible approaches 


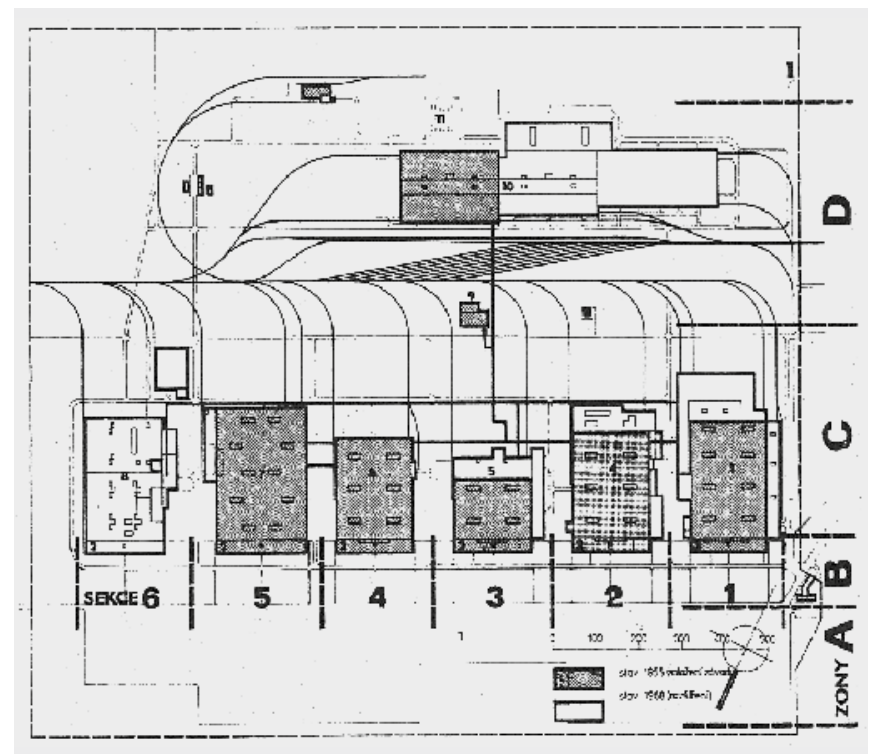

THE METHOD OF ZONES AND

SECTIONS USING THE EXAMPLE

OF A UNIVERSAL FACTORY

METODA ZÓN A SEKCÍNA PŘíKLADU

UNIVERZÁLNÍHO ZÁVODU

Source Zdroj: archive of Tomáśs

Šenberger

to the re-use of railway buildings from less invasive to very invasive, from mono-functional to multi-functional. These formulations were very important, as the mentioned industrial methodology only carefully opens the topic. The second one was a case study of the Transgas company's Central Dispatching Centre of Transit Pipelines ${ }^{12}$, an iconic building in central Prague in the style of New Brutalism, which was recently demolished. Any potential of new use or re-use (including a possible conversion to a branch of the Centre Pompidou) was completely ignored. These two case studies showed that the assessment of these buildings is very specific and must be approached with knowledge of their economic history, specific typologies, constructions and, above all, without prejudice (in the case of Transgas, the perception of the aesthetics of the New Brutalism was a greater problem than the perception of this building as a component of the state infrastructure).

The sample was, in other words, entirely unrepresentative; however, it contained buildings that can be also found in other inventory projects noted here (and we need to add that an important source that could be systematized is also the Industrial Topography of the Research Centre for Industrial Heritage (VCPD) under FA CTU in Prague ${ }^{13}$ ). It is obvious that if we are to select representatives for monumental protection, these lists must be based on a deeper knowledge - there is also a need to evaluate typical as well as atypical examples and to be able to understand typology as a category by itself.

\section{Typological Innovations}

From the perspective of developing standardisation, the topic was addressed by Jan Zikmund. ${ }^{14}$ His summary of the general history of the postwar development of Czech industry and the establishment of individual typologically specialized design institutes, ${ }^{15}$ forming the core system of that time, is of major significance.

The current body of research aims to address the development of particular typologies. ${ }^{16}$ The text below summarises some of the results. ${ }^{17}$ Generally, this period was marked by the optimisation of the relationship between the preparation and actual implementation of manufacturing buildings, but also by the search for new, progressive concepts of industrial factories, based on the latest typological innovations, which went hand in hand with the search for a valuable architectural aesthetic. Criticism of "socialist construction style and developments" and the resulting lack of interest in these buildings is, to a degree misplaced, as similar developments took place in the West and had certain specifics. ${ }^{18}$ The search for new typological solutions in industry was in fact a worldwide task.

Since the 1950s, industrial buildings have been given great national economic importance and priority over other typologies. Typological and structural issues were addressed by individual specialised building planning institutes, but also, for example, by the industrial section of the Union of Architects, which organised so-called "actives" (meetings), the results of which were published in professional journals and publications. Here we also encounter examples of studies and 
BYTEX TEXTILE WORKS, NÁMĚŠŤ NAD OSLAVOU. ZDENĚKK PLESNÍK, LUDVÍK JUNGWIRTH, CENTROPROJEKT, 1974-1977.

BYTEX NÁMĚŠŤ NAD OSLAVOU. ZDENĚK PLESNÍK, LUDVÍK JUNGWIRTH, CENTROPROJEKT, $1974-1977$

Source Zdroj: www

industrialnitopografie.cz, 2021
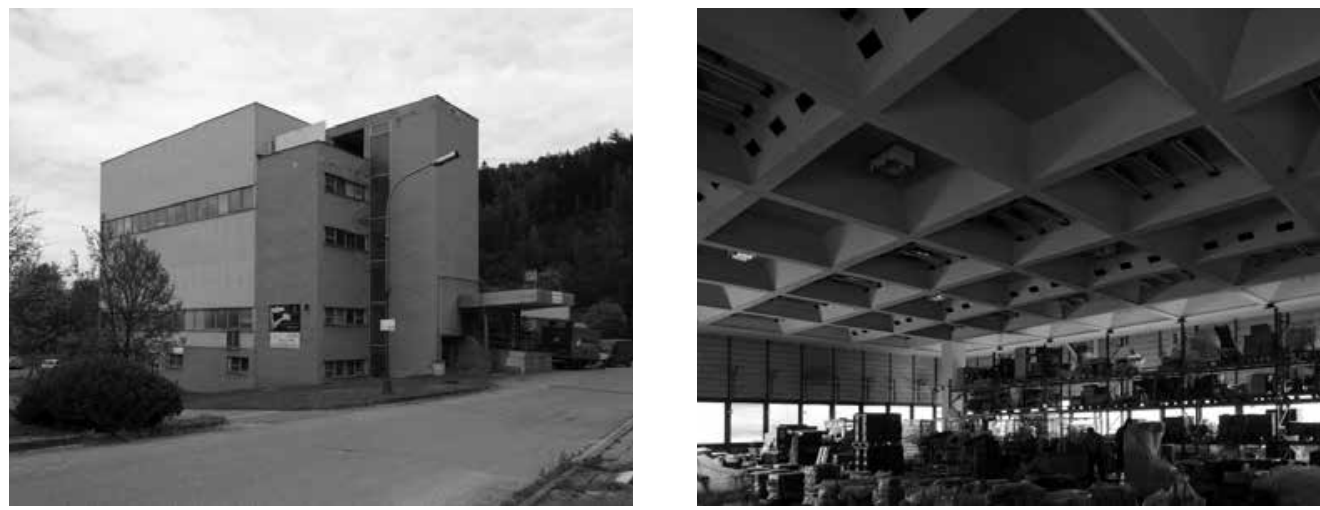

\section{THE PRESENT BOHEMIA \\ GLASSWORKS, SVĚTLÁNAD \\ SÁZAVOU. JIŘí KADLEC, \\ SKLOPROJEKT, 1975.}

DNEŠNÍ SKLÁRNA BOHEMIA VE

SVĚTLÉ NAD SÁZAVOU. JIŘí KADLEC, SKLOPROJEKT, 1975

Photo Foto: Tomáš Šenberger, 2021

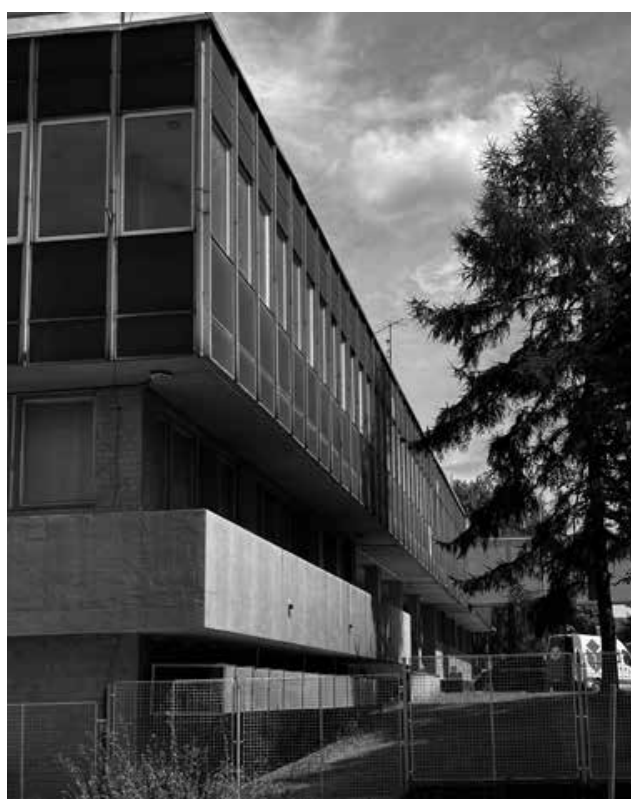

implementations from abroad, where "turnkey" enterprises were exported (construction carried out in Africa, India, the Democratic People's Republic of Korea, Vietnam, Cuba, etc.).

As for the general development of typology, we can conclude that the first important innovation in industrial typology was the introduction of a new concept in the early 1960s: the Production Plant Master Plan (Generel), which served to coordinate the location of all buildings, utility systems, roads, and green areas. For the design, the method used was one of "zones and sections", i.e., an organized area divided by perpendicular zones. ${ }^{19}$ These pragmatic efforts to reduce the amount of agricultural land occupied, to rationalise and shorten transport links, and to save on energy requirements resulted in major typological innovations, finished with quality architecture. Another important factor was, thanks in part to international journals, at least a distant contact with the outside world.

In the design of universal, multi-purpose factories, the new tendencies were mainly reflected in the concept of factories concentrated in a single premise - a "monoblock", organized under one roof, for the minimization of building area and energy loss. The first monoblock of the Plastimat plant in Liberec, built in 1965, has already been listed. ${ }^{20}$ This was followed by the Barum tyre plant in Otrokovice (Chemoprojekt Pardubice, project by Jan Jandera in 1964, implementation in 1972), while the elegant monoblock of the FEZKO textile plant in Strakonice (Centroprojekt Gottwaldov, project by Zdeněk Přibyl in 1967, implementation in 1972) housed a windowless knitting shop floor and footage adjustments on an area exceeding $2000 \mathrm{~m}^{2}$. An iconic set of maximally concentrated assemblies in one monoblock was the Oděvní závody Prostějov [Clothing Plant Prostějov] (Centroprojekt, Zdeněk Plesník in 1963, demolished in 2016). For the five-storey production building of 

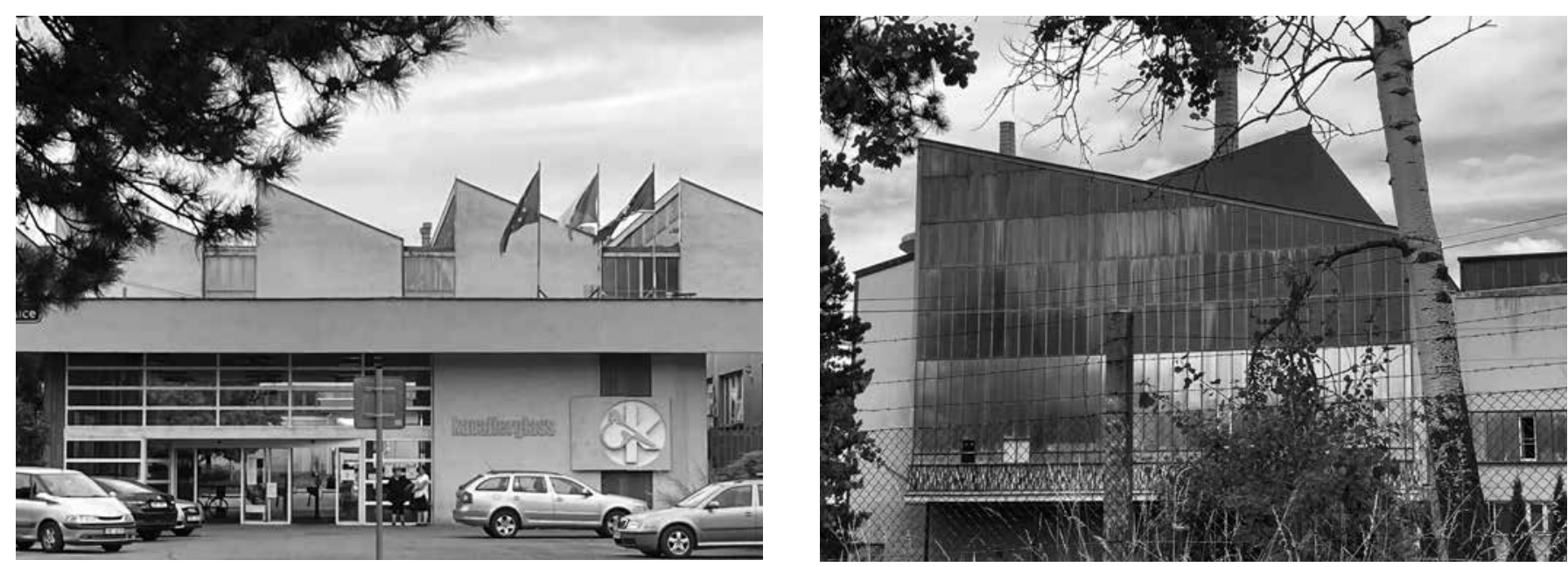

THE KAVALIER GLASSWORKS,

SÁZAVA NAD SÁZAVOU,

CONNECTED TO A RESIDENTIAL UNIT. JIŘí KADLEC ET AL., $1969-1973$.

the Gustav Kliment Shoe Factory in Znojmo (Milan Možný, 1976), a steel structure with a modular mesh of superior dimensions $(6 \times 12 \mathrm{~m})$ was used. The possibilities of large-span construction of multi-storey buildings were also tested by the construction of an experimental division for manufacturing industry in Náměšt' nad Oslavou with a steel construction for a span of $18 \times 18 \mathrm{~m}$

SKLÁRNA KAVALIER SÁZAVANAD SÁZAVOU, KTERÁ BYLA NAPOJENA INA OBYTNÝ CELEK. JIŘÍ KADLEC A KOL., $1969-1973$

Photo Foto: Tomáššenberger, 2021 (Centroprojekt, Zdeněk Plesník, Ludvík Jungwirth, 1977). Among engineering plants, the exemplary construction by the Prague-based Projekta - TOS in Hostivař - stands out (Projekta, František Havlík, Danuše Matoušová, 1974). The indoor monoblock on an area of more than 2,0oo $\mathrm{m}^{2}$ is composed of five parallel and two transverse naves with a span of $24 \mathrm{~m}$, along with an innovative Feal-Sidalvar aluminium facade. Another major example is the construction of the Bohemia glassworks in Světlá nad Sázavou (Skloprojekt, Jiři Kadlec, 1975) with textbook zoning and a two-storey monoblock with a saw-tooth roof, which also included a glassworks hall. A surprising solution was used by the same architect for the completion of the Kavalier technical glassworks in the town of Sázava nad Sázavou (Jiři Kadlec et al., $1969-1973$ ).

In specialized, single-purpose factories, the new tendencies were manifested primarily by the effort to remove the building facade from in front of the technological equipment - the unveiling of interesting production equipment, from a design perspective, saved both for investment and expected operating costs. One of the first such significant implementations was the synthetic rubber plant Kaučuk in the town of Kralupy nad Vltavou (Chemoprojekt, Miroslav Koukolík, 1958 - 1963). Another example of an excellent design of free-standing apparatus are the pyrolysis furnaces in the Petrochemie II plant in Záluží u Most (Chemoprojekt, team of authors, 1976 - 1980). In the Počerady I and II thermal power plant (Energoprojekt, Alexander Gudev, 1969 and 1977), a variant was tested involving the maximum possible exposure of all operating parts. Even though the solution implied financial savings, it was not used for further implementations due to the local climatic conditions.

The deepening criticism of production processes, still based in the early days of the industrial age on a 'coal-steel-machinery' axis, together with a series of other events in early 1970s, gradually led to fundamental changes in the approach to production technology and thus to the design of industrial plants. First were the Club of Rome reports about the critical condition of the environment in 1972. Second was the first energy crisis in Europe in the mid-197os and the overall crisis of the European economy, followed by a dramatic decline in industrial production, and the departure of textile production and especially of heavy industry from Europe to other world destinations, which triggered new approaches to industry in general, industrial buildings not excluded. The change came hand in hand with the development of computers and the introduction of computerised production control and the subsequent automation of machine production. The change affecting European industry as well as the design of industrial plants, today termed the third industrial revolution, was genuinely fundamental during the 1970s. In Czechoslovakia, for obvious historical reasons, some innovations were delayed until the late 1980 os and early 1990s, and for the same reasons conversion issues, for example, also made their appearance much later than in developed democracies. ${ }^{21}$

We also identified a slightly different list of architects than the one usually associated with construction of civil buildings of that time. It includes overlooked yet highly interesting architects 
such as Rudolf Holý, Miroslav Göpfert, Jiř́ Kadlec, Zdeněk Přibyl, Ludvík Jungwirth and others noted above, who were in fact unjustly neglected compared to the architects of "common typologies". The list is of course supplemented by well-known names such as Zdeněk Plesník, Vladimír Karfík, Karel Hubáček and Emil Hlaváček, who also appeared more often with their colleagues as winners of architectural competitions mentioned below.

The evaluation of buildings and the selection of representative buildings for heritage protection must therefore be based on the fundamental understanding of a particular typology. However, this is an aspect closer to the original architectural thinking about the design of industrial buildings than the aesthetic aspect that tends to prevail in the field of contemporary heritage care and appeared in some of the previously mentioned inventory works. At this point, the research refers to the aforementioned methodological assessment of industrial heritage developed by Miloš Matěj and Michaela Ryšková.

\section{Architectural Competitions for Industrial Buildings and Development of Typologies}

Another area of research deals with a more specific issue, though an interesting area characterised by a sorting of opinions on typological solutions: competitions. The decade of the $1960 \mathrm{os}$ was characterised by a great competition boom, with competitions systematically announced for almost all typologies and published in the professional press of the time (in particular, the journals Architektura ČSR/ČSSR and Československý architect - here in a special edition organised by the Union of Architects). ${ }^{22}$ For investors, they formed a chance to acquire a high-quality or interesting project in the otherwise uniform environment of socialist building planning institutes. However, there were few competitions for purely industrial buildings (only three were mapped), therefore research in this direction is still ongoing. Several competitions were organised for the construction of telecommunication buildings and for transport: bridges, airports, etc. However, many tenders were only mentioned in the press, although they formed quite interesting projects, for example for petrol stations or automotive service facilities. ${ }^{23}$

Many architects warned against competitions for industrial buildings, objecting to the increased volume of interesting competitions that left insufficient time for familiarisation with the issues to be solved. From the examples studied, this was particularly true of telecommunications buildings; but similar discussions were also held in the case of medical and sports facilities. At the same time, their desire was to gain a better understanding of the typologies that were then rapidly developing through competitions (even through non-binding discussions) and to reconcile typological efforts with a degree of free progressivity. In the area of industry, however, it became clear during the 196os that the degree of specialization was so high that only specialized institutes could deal with a particular sector, and so most of the competitions announced were either intra-institutional or inter-institutional. What follows is a brief list of selected examples that illustrate the various reasons for announcing competitions (standardization, search for unconventional solutions, representation, resolution of typology, etc.).

An example of a competition published in greater detail was the intra-institutional competition of the State Building Planning Institute Projekta-Praha for the development of standardised documentation of an energy block for a medium-sized engineering plant (1960; the 2nd prize was awarded to Jiři Brusnický et al.; only one other design, by the team of architects Dejmek, Fuka, Kavka, Hynar, Jiroušek, Mihalčík, Skořepa, was published). ${ }^{24}$ At that time, power supply equipment varied from plant to plant, and the standardised documents were intended to resolve the situation. The competition asked applicants to design an energy block where all the operation parts would be integrated (usually steam boilers, transformer stations, compressor stations, offices, workshops, warehouses, and sanitary facilities were built separately). The building was supposed to be architecturally refined, inexpensive, and adaptable to the changing demands of the plant (operational, urban). Three teams took part in the competition, and only the winning design by Jiř́ Brusnický from Projekta-Praha was published. It divided the energy block into two operationally, structurally, and architecturally different sections: a boiler room with a steel structure, while the building containing other facilities was of reinforced concrete prefabricated parts with glazing. The project clearly shows the architects' efforts to provide a worthwhile architectural solution for a standardised building and to break away from the confines of an outdated socialist realism through purely modernist forms. 


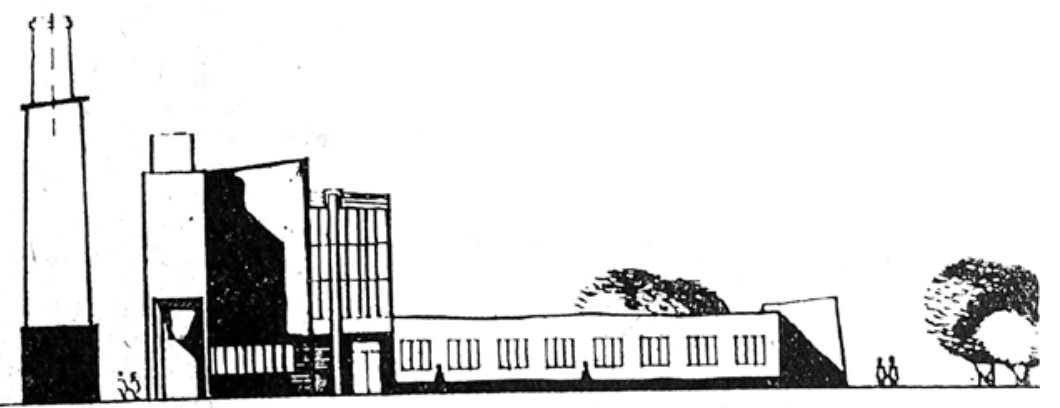

AN EXAMPLE OF A COMPETITION IN

THE FIELD OF STANDARDISATION.

THE INTERNAL COMPETITION

FOR THE STATE DESIGN INSTITUTE

PROJEKTA - PRAHA FOR

PREPARING STANDARDISED

DOCUMENTATION FOR ENERGY

BLOCKS FOR A MEDIUM-SIZED

ENGINEERING PLANT. DESIGN

BY THE TEAM DEJMEK - FUKA

- KAVKA - HYNAR - JIROUŠEK -

MIHALČÍK - SKOŘEPA.

PŘÍKLAD SOUTĚŽE Z OBLASTI

TYPIZACE. VNITROÚSTAVNÍ

SOUTĚŽ SPÚ PROJEKTA - PRAHA

NA VYPRACOVÁNÍ TYPOVÝCH

PODKLADŮ ENERGOBLOKU PRO STŘEDNÍSTROJÍRENSKÝ ZÁVOD.

NÁVRH KOLEKTIVU DEJMEK -

FUKA - KAVKA - HYNAR -

JIROUŠEK - MIHALČÍK - SKOŘEPA.

Source Zdroj: HLAVÁČEK, Emil, 1960

Soutěž na návrh typového energobloku.

Československý architekt. 6(13), p. 5

The competitions for the entrance premises of industrial plants, containing administrative buildings, personal and secondary technical facilities, were published in more extensive detail. Preplant areas were given increased attention, because there was a certain focus on the presentation of state-owned enterprises. The West also sought optimal solutions for entrance areas, often architecturally unconventional. The competitions were complex, dealing with urban planning connections (to the surrounding buildings, transport, greenery) and, of course, with interesting architectural and artistic solutions, presenting an already progressive international style or New Brutalism. In general terms, the aim was to create appropriate links between these spaces and the plant's general development plan.

A typical example is the institutional competition of the Kovoprojekta enterprise for the conceptual urban and architectural design of the pre-plant area of AZNP Mladá Boleslav (today's Skoda Auto) (1st phase 1965; 2nd prize Jiří Brusnický and Emil Hlaváček; 2nd prize Karel Flanderka; 2nd phase 1966; ${ }^{25}$ 1st prize Jiří Brusnický and Emil Hlaváček). ${ }^{26}$ The competition involved not only an administrative building, but also assembly, representation and exhibition spaces, a medical clinic, canteen, and a technical-metallurgical research building. Intended as the dominant landmark was a high-rise office building, which most of the designers proposed in a pure International style with cool technicist lines. The Mladá Boleslav implementations are today among the best examples of their time and are the subject of detailed research by Prof. Michal Hlaváček at CTU in Prague and his PhD students.

A competition with a notably unconventional assignment, including the possibility of public participation, was held for the water treatment plant in Nová Ves near Frýdlant (published 1969; 1st prize Ivo Klimeš; other prizes and winners not mentioned). The competition, however, only addressed artistic design of the entrance area of the water treatment plant, though it reveals the importance of connecting industrial buildings with a very distinctive artistic design. ${ }^{27}$

Several competitions were held in the field of transportation buildings. For example, airports, being a matter of national importance, were built in Košice and Bratislava through architectural competitions. Typologically, the competition for a set of terminal buildings of the new airport 


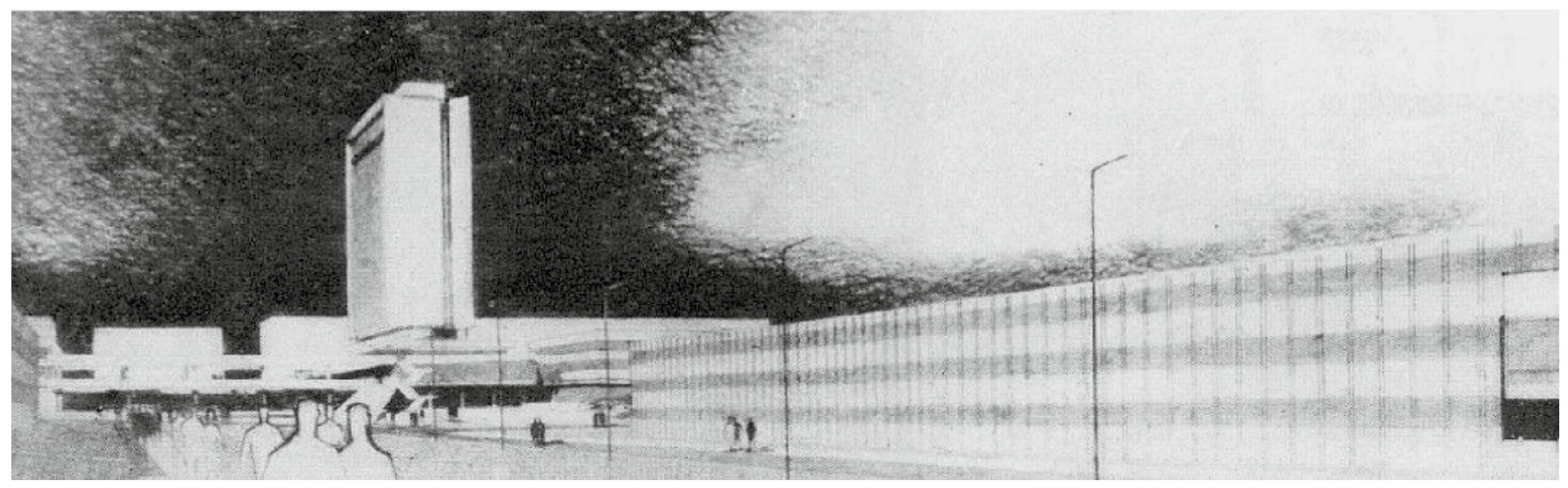

INTERNAL COMPETITION IN THE INSTITUTE KOVOPROJEKTA FOR AN IDEAL URBANISTIC AND ARCHITECTURAL DESIGN FOR THE PRE-PLANT AREA OF AZNP MLADÁ BOLESLAV. PHASE 1: 1965, PHASE 2: J. BRUSNICKÝ, E. HLAVÁČEK, 1ST PRIZE FOR PHASE 2. THE DESIGN OF PRE-PLANT AREAS FOR INDUSTRIAL ENTERPRISES WAS A MAJOR TASK IN THE 1960S. IN THE CASE OF AZNP MLADÁ BOLESLAV, IT WAS NEVER REALISED AS SUCH.

ÚSTAVNÍ SOUTĚŽ KOVOPROJEKTY NA IDEOVÉ URBANISTICKÉ A ARCHITEKTONICKÉ ŘEŠEN PŘEDZÁVODNÍ ČÁSTI AZNP MLADÁ BOLESLAV. 1. FÁZE 1965 2. FAZE 1966. J. BRUSNICKY, E. HLAVÁČEK, 1. CENA DRUHÁ FÁZE. ŘEŠENI PŘEDZÁVODNÍCH ČÁSTÍ ZÁVODU゚ BYLO VELKÝM ÚKOLEM ŠEDESÁTÝCH LET. VPŘíPADĚ AZNP MLADÁ BOLESLAV NEBYLO TAKTO REALIZOVÁNO.

Source Zdroj: KOVAŘíK, Emil, 1967 Vstupní část automobilových závodů v Mladé Boleslavi. Architektura ČSSR 26(11), pp. $375-362$

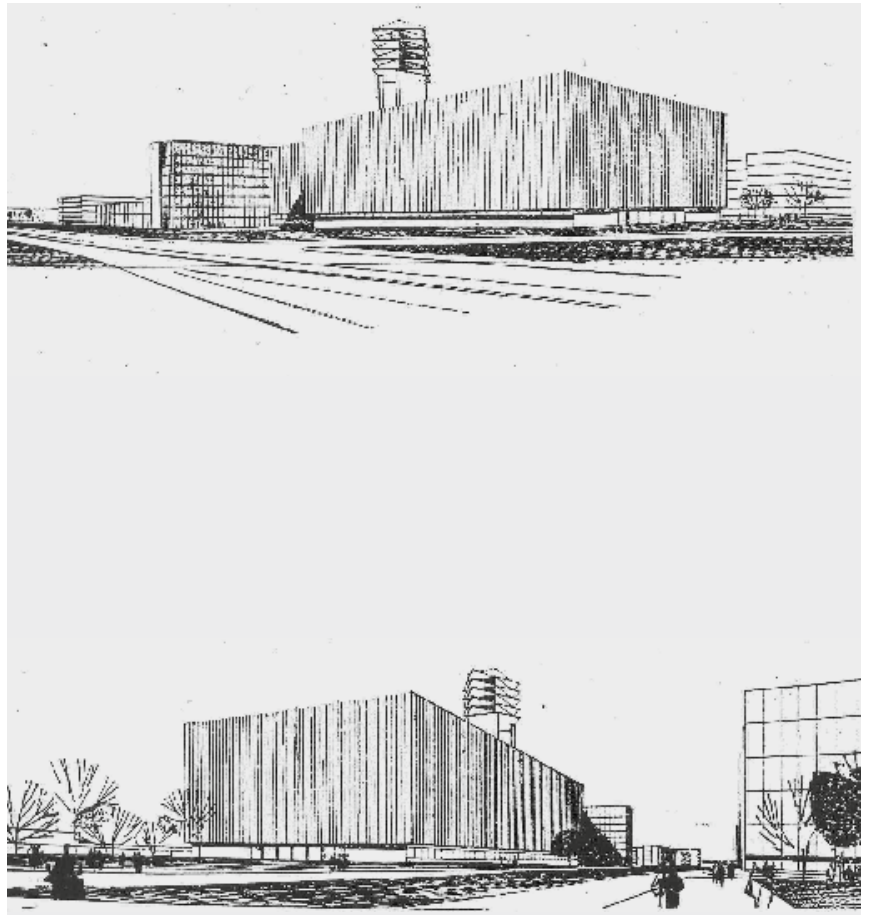

RESTRICTED, NON-ANONYMOUS INTER-INSTITUTE COMPETITION FOR THE CENTRAL TELECOMMUNICATION BUILDING, PRAGUE 3 PHASE 1: 1964, PHASE 2: 1965. PERSPECTIVE FROM PHASE 2 , JOSEF HRUBÝ, ZDENĚK POKORNÝ, FRANTIŠEK ŠTRÁCHAL, FRANTIŠEK CUBR. FROM THE TECHNICAL-TECHNOLOGICAL STANDPOINT, THE PARAMETERS OF THE TRANSMISSION TOWER WERE NOT MET.

OMEZENÁ NEANONYMNÍ, MEZIÚSTAVNÍ SOUTĚŽ NA ÚSTŘEDNI TELEKOMUNIKAČNÍ BUDOVU $\checkmark$ PRAZE 3, 1. FAZE 1964, 2. FAZE 1965. PERSPEKTIVA Z DRUHÉ FÁZE SOUTĚŽE JOSEF HRUBÝ, ZDENĚK POKORNÝ, FRANTIŠEK ŠTRÁCHAL, FRANTIŠEK CUBR. Z TECHNICKOTECHNOLOGICKÉHO HLEDISKA NEBYLY ZVLÁDNUTY PARAMETRY VYSÍLACÍ VĚŽE.

Source Zdroj: CAJTHAML, Miloslav, 1965. Omezená neanonymní soutěž na ústřední telekomunikační budovu v Praze - 2. fáze. Architektura ČSSR 24(15), pp. $633-637$

in Prague-Ruzyně (1959; prizes to the team of Vladimír Karfík, Anton Rokošný at al.; the team of Otakar Štěpánek, Emil Hlaváček, at al.; the team of Jiř́ Eisenreich at al.; the team of Josef Danda). The winning team, which had already participated in previous competitions for Slovak airports, came up with a generous solution for terminal buildings. One advantageous factor was the adaptability of the set of buildings for future development (up until 1980), while the International Style aesthetics made the design a truly representative display of socialist Czechoslovakia.

Another large category was formed by telecommunications buildings, which are currently the most detailed subject of research. One typical example is the competition for the Prague telecommunications exchange, intended to produce a world-class facility (two-phase limited, non-anonymous inter-institutional competition for the central telecommunications building in Prague 3; 1st phase 1964; 2nd prize to the team of the Regional Land Authority Praha - Josef Hrubý, Zdeněk Pokorný, František Štráchal, František Cubr; 2nd phase 1965; 1st prize to Josef Hrubý, Zdeněk Pokorný, František Štráchal, František Cubr). ${ }^{28}$ From the aspect of typological discussion, it was essential to familiarize the architects with the issue, and the state investor organised excursions and discussions on individual plant operations. Despite these efforts, the results of the first round were not satisfactory, because, among other things, the competition was poorly prepared, since the condition of placing the broadcasting operations at a height of at least 60 metres was not included 


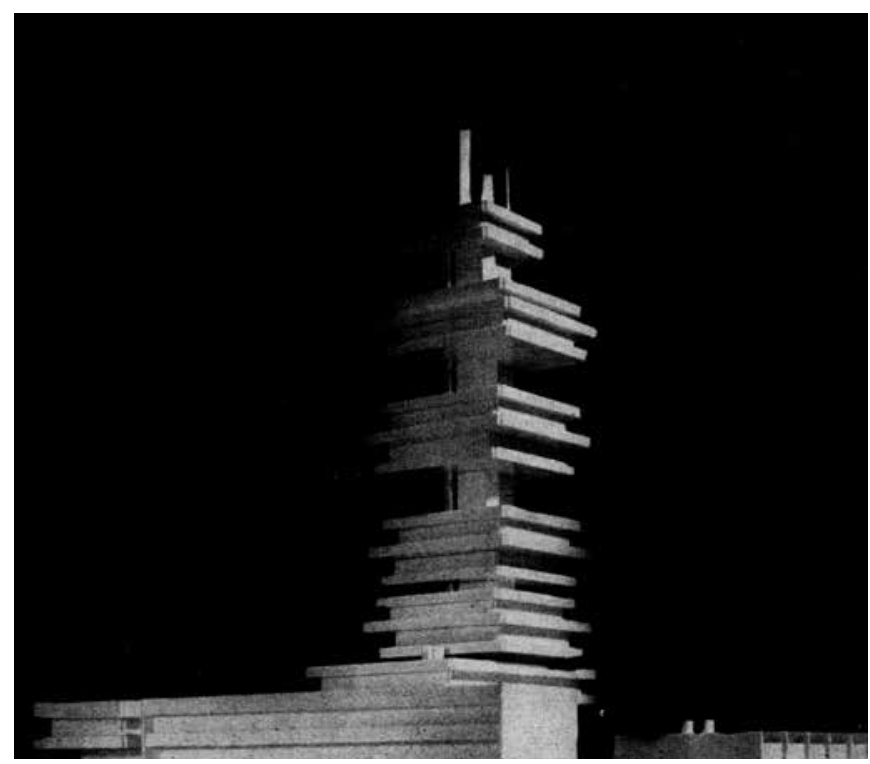

RESTRICTED, NON-ANONYMOUS

COMPETITION FOR DESIGN

OF A BUILDING FOR RADIO

TRANSMISSION CONNECTIONS,

PRAGUE-STRAHOV.1967,

J. STRUHAR ET AL., 1ST REDUCED

PRIZE. AN EXAMPLE OF ANOTHER

COMPETITION WHERE DISCUSSION

FOCUSED ON THE TECHNICAL

QUALITIES OF THE DESIGN

AGAINST ITS PROGRESSIVE FORM.
OMEZENA NEANONYMNI SOUTĚŽ NA ŘEŠENÍ OBJEKTU RADIORELÉOVÝCH SPOJŮ $\checkmark$ PRAZE NA STRAHOVĚ, 1967 J. STRUHAR A KOL., 1. SNÍŽENÁ CENA. PŘÍKLAD SOUTĚŽE, KDE OPĚT PROBÍHALA DISKUZE NAD TECHNICKOU KVALITOU NÁVRHŮ VS. POKROKOVOU FORMOU.

Source Zdroj: NOVOTNÝ, Jiř́, 1968 Soutěž na řešení objektu radioreléových spojů v Praze na Strahově. Architektura ČSSR. 27(9), pp. $288-292$

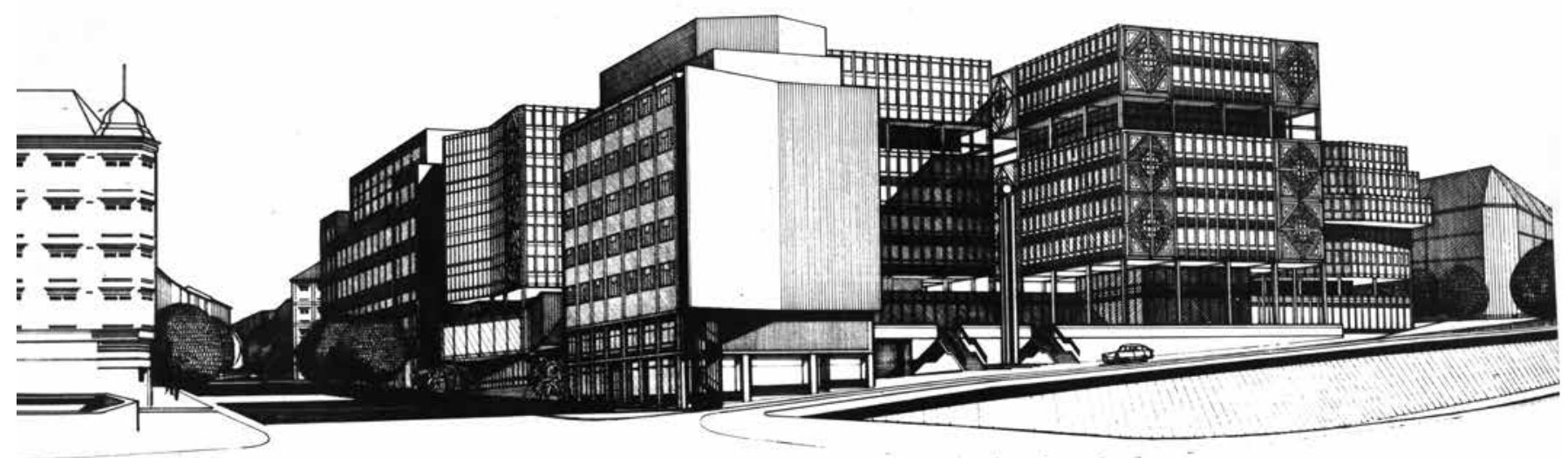

PUBLIC ANONYMOUS

ARCHITECTURAL-URBANISTIC COMPETITION FOR THE IDEAL DESIGN OF THE BUILDING OF THE CENTRAL GAS DISTRIBUTION PRAGUE 2. PERSPECTIVE RENDERING FROM ROUND 2 , WINNING DESIGN BY IVO LOOS AND JINDŘICH MALÁTEK.

VEŘEJNÁ ANONYMNÍ ARCHITEKTONICKO-URBANISTICKA SOUTĚŽ NA IDEOVÝ NÁVRH BUDOVY ÚSTŘEDNÍHO PLYNÁRENSKÉHO DISPEČINKU $\checkmark$ PRAZE 2. PERSPEKTIVA Z DRUHÉHO KOLA SOUTĚŽE VÍTĚZNÉHO NÁVRHU IVA LOOSE A JINDŘICHA MALÁTKA.

Source Zdroj: private archive of Lucie Loosová

in the competition assignment but proved to be key for further development of the project (and underrated by technicians), hence the participants themselves concentrated only on the formal solution. The jury therefore recommended a limited competition between the two highest-ranked teams, which had already developed their designs with expert advisors. Only in the second phase of the competition did the winners, Josef Hrubý et al., add the form of the broadcasting tower with its distinctive silhouette to the horizontal complex of office buildings with atria. This result is an interesting example of following the development of typology directly during the preparation process.

No less important for the debate was the restricted, non-anonymous competition for the radio transmission building in Strahov, Prague (1968; 1st prize to Jozef Struhar et al.). ${ }^{29}$ This competition also reflects a similar „struggle“ of architects between form, structure, and typology, with the form again dominating in the initial phases and providing the most interesting component of the design.

As part of the aforementioned NAKI II project, the author, in collaboration with Nikolay Brankov, carried out detailed research on the competition for the now demolished Transgas ${ }^{30}$ building complex, which showed the whole spectrum of the issue from the competition assignment through the tender to the evaluation of the completed buildings. In the case of the strategic Transgas building, some facts have not been published anywhere and the archives have disappeared, another instance revealing the significant limitations on research into the buildings of that era. 
THE HAVÍŘOV RAILWAY STATION WAS NEVER GIVEN HERITAGE PROTECTION. IT WAS SAVED THANKS TO CIVIC INITIATIVES SUCH AS “ARCHITECTURE MINE". AN EXAMPLE OF A NEW CULTURAL USE. ARCHITECT JOSEF HREJSEMNOU, 1969.

NÁDRAŽí HAVÍŘOV NEBYLO PROHLÁŠENO KULTURNI

PAMÁTKOU.KZACHOVÁNÍNÁDRAŽ PŘISPĚLY OBČANSKÉ INICIATIVY JAKO DŮL ARCHITEKTURY PŘÍKLAD NOVÉHO KULTURNÍHO VYUŽITÍ. ARCHITEKT JOSEF HREJSEMNOU, 1969

Photo Foto: Lenka Popelová, 2017

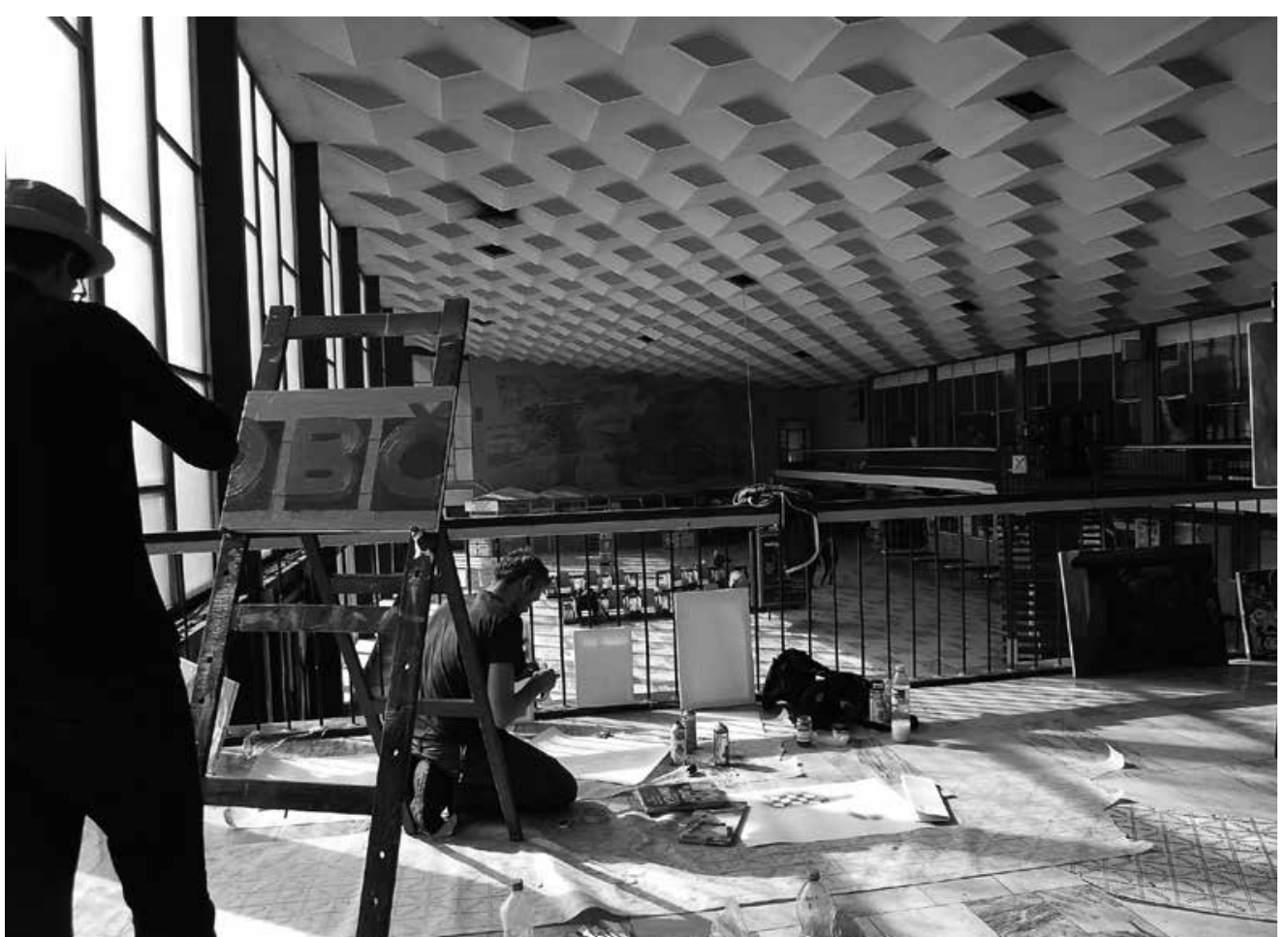

\section{Possibilities of Re-Use and Conclusions}

All the same, from the aspect of typological development, industrial buildings from the second half of the 2oth century are, at least in the Czech Republic, still functional as demonstrated by several examples mentioned herein. It is these structures which the research is trying to systematize, and with regard to the upcoming "industrial revolution 4.0" are potentially at risk of disappearance due to the very nature of the promoted change. If we see industrial heritage as part of cultural heritage, and in general architectural monuments from the second half of the zoth century are no longer questioned in this aspect, it is finally a good time to look at the evaluation of industrial buildings from this period. Their qualities, based on a highly conceptual approach that took into account the needs of new production technologies and the possibilities of unusual designs, but also the efforts for attractive architectural solutions and the first indications of environmental protection, undoubtedly deserve our attention today.

Of primary importance is not the sheer number of proposals for the conservation of these factories, but rather the serious evaluation of their qualities in all monitored criteria, and the subsequent selection of a few exceptional representatives (which have already emerged from the research) and their inclusion in the list of immovable cultural monuments.

There is a need to understand and select exemplary works for protection, not only those of excellence but also the typical productions of the time. We need to formulate the possibilities of new use, which may be specific, for example, due to special aspects of design, aesthetics, location, etc., and lie outside the common experience with conversions of historic buildings.

Quite a few examples to be documented can be found, and it would be a shame to miss out on this unique opportunity, as happened with some of the buildings mentioned above, or with many more narrowly specified examples of industrial architecture from the late $19^{\text {th }}$ and first half of the 2oth century. This decision is related to the idea of the potential re-use of these buildings once they are no longer used for their original production function. This concept is also now emerging in the professional organisation TICCIH, where Lenka Popelová presented the current inventory of our postwar textile factories (compiled together with Tomáš Šenberger) at a workshop on textile factories, ${ }^{31}$ itself an entirely new topic for TICCIH as well.

The contemporary debate makes it clear that state protection is not the only possible preservation strategy and in fact fails in many cases (see e.g., the discussion on the new use of Vítkovice railway station or Transgas). Therefore, all possible methods of protecting selected buildings must 
THE CZECHOSLOVAK ARMY MINE. AN EXAMPLE OF LANDSCAPE CHANGES CAUSED BY INDUSTRIAL ACTIVITY THAT NONETHELESS BRING POSSIBILITIES FOR NEW USE.

DŮL ČESKOSLOVENSKÉ ARMÁDY. PŘÍKLAD ZMĚN KRAJINY VLIVEM PRŮMYSLOVÉ ČINNOSTI, KTERÉ ALE PŘINÁŠEJÍ MOŽNOSTI NOVÉHO VYUŽITÍ.

Photo Foto: Lenka Popelová, 2019

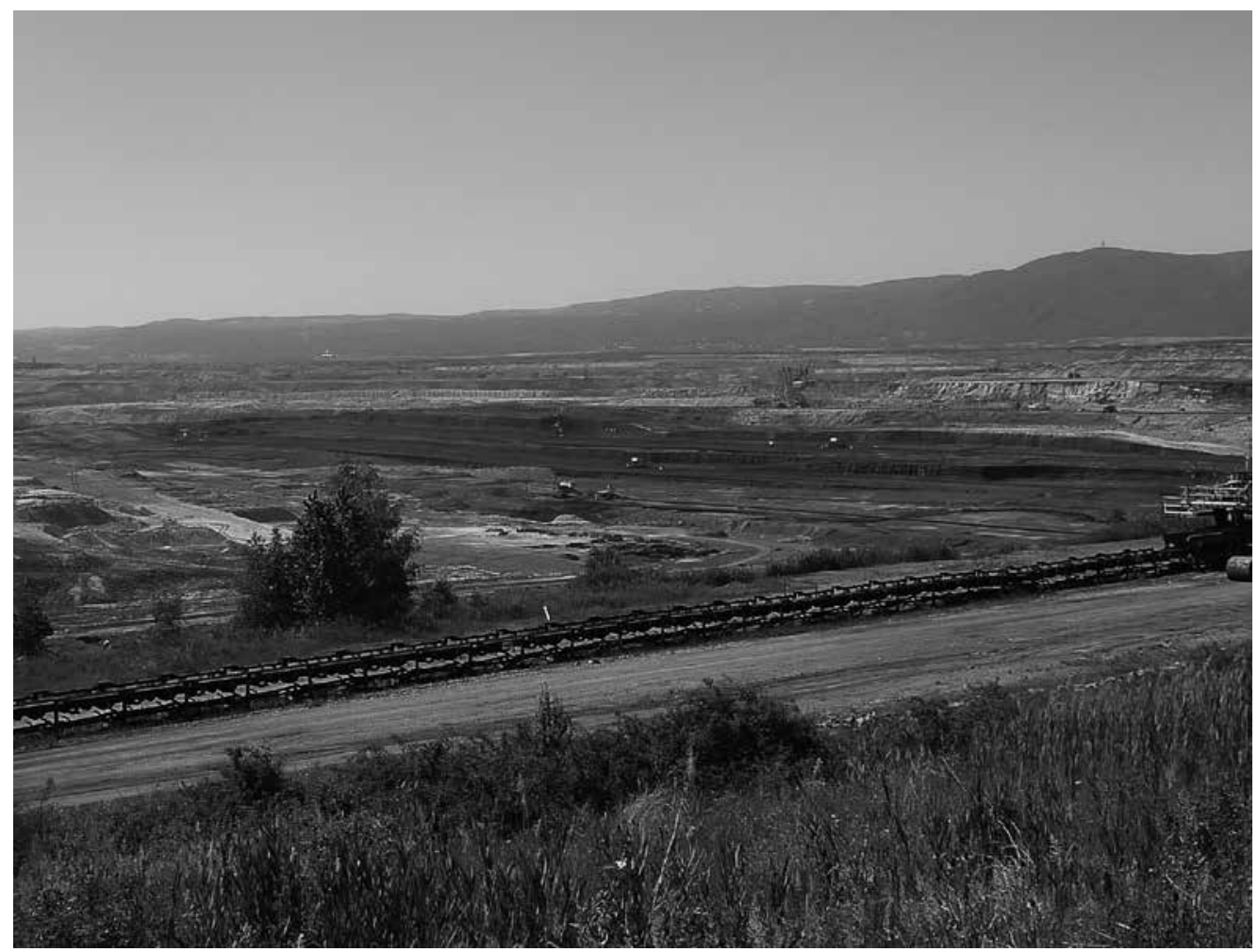

also be the subject of research and need to be applied in practice. An interesting example in this context is the late modernist railway station in Haviŕov (Josef Hrejsemnou, 1969), where the renovation of the building with its large glass façade was not initiated by its user or owner "from the inside", but by initiatives of the professional and lay public seeking to save it, figuratively speaking, "from the outside". The lack of appreciation for this station's perceived value (monument protection was rejected), the inappropriate concept of the conversion design, the absence of public discussion and architectural competition - all these factors contributed to the formation of an initiative of experts and activists striving to save it. The Architecture Mine Association has organised numerous activities in the building for various groups of visitors: guided tours, lectures, cultural events, a minimalist café, and artist residencies. In this way, it has significantly supported the preservation of the building, which has the chance to show how it will live with a partially new functional use ${ }^{32}$ and serve as a model for further arguments in the protection of postwar heritage.

The issue is that today, quite rapidly, we are losing an interesting cultural layer with many iconic buildings that represented the building production and technical effort of that period. Therefore, there is a need to take action. At the same time, this issue equally involves the transformation of landscapes - e.g., the North Bohemian Basin, a region now awaiting transformation on a massive scale. Re-used technical structures should serve as a starting point for this transformation - if there is a will. Similarly, it is also necessary to re-open discussion on this topic within the current monument protection bodies, as both of the recently published methodologies (the Methodology for the Evaluation and Protection of Industrial Heritage from the Perspective of Heritage Management ${ }^{33}$ and the Conservation Methodology for the Buildings of the Second Half of the 2oth Century ${ }^{34}$ ), have failed to address the topic. 
1 VRABELOVÁ, Renata and GORYCZKOVÁ, Nad’a (eds.), POPELOVÁ, Lenka, SEDLÁKOVÁ, Radomíra, ŠENBERGER, Tomáš, ŠKRANC, Pavel and URLICH, Petr, 2020. Metodika hodnocení a ochrany staveb 2. poloviny 20. století (se zaměrením na architektonické dèdictví 6o. a 7o. let) vzhledem k jejich (možné) památkové ochraně. Brno: NPÚ, [also online]. Available at <https://www.ma607o.cz/ pamatky/architektura- 6o-a-7o-let/ke stazeni/publikace/Metodika_hodnoceni_ochrany_staveb.pdf > [Accessed 20 November 2020].

2 Research project Analýza a prezentace hodnot moderní architektury 60. a 7o. let 20. století jako součásti národní a kulturní identity $\check{C} R$ was funded from the applied research and development of the national and cultural identity, NAKI II programme of the Ministry of Culture of the Czech Republic and administered by the National Heritage Institute. The project runs from 2016 through 2020, with the Faculty of Civil Engineering, CTU in Prague being one of the co-investigators.

3 MATĚJ, Miloš and RYŠKOVÁ, Michalela, 2018. Metodika hodnoceni a ochrany průmyslového dédictví z pohledu památkové péče. Ostrava: NPÚ.

4 The following text defines industrial heritage according to the Charter of Industrial Heritage/ TICCIH. See THE NIZHNY TAGIL CHARTER FOR THE INDUSTRIAL HERITAGE, 2003, https://www.icomos. org/18thapril/2006/nizhny-tagil-charter-e.pdf, [Accessed 10 August 2020]. It defines it in a broad sense, as objects linked to production, distribution, and transport. According to the definition, this also includes other typological types, e.g., administrative buildings if they are part of or related to production units.

5 See VORLÍK, Petr, BRŮHOVÁ, Klára, ZIKMUND, Jan, GUZIK, Hubert, POPELOVÁ, Lenka, VICHERKOVÁ, Veronika and HORÁČEK, Martin et al., 2017. Česká poválečná architektura „pod ochranou a bez". 53(4), pp. 456 - 462.

6 Information differs source by source.

7 See ZIKMUND, Jan, 2020. Hledání univerzality. Kontexty průmyslové architektury v Československu (1945 1965). Praha: Faculty of Architecture, CTU in Prague, pp. $182-183$.

8 VORLÍK, Petr (ed.) and ZIKMUND, Jan, PAVEL, Miroslav, Pavel, POPELOVÁ, Lenka (podněty/proposals), 2017. Náměty na Kulturní památky - pracovní skupina pro poválečnou architekturu při. ČNK ICOMOS, 2017.

9 See https://www.npu.cz/ cs/npu-a-pamatkova-pece/ npu-jako-instituce/cinnosti/ veda-a-vyzkum/9534-analyza-aprezentace-hodnot-moderni-architek- tury-6o-a-7o-let-2o-stoleti-jako-soucasti-narodni-a-kulturni-identity-cr, [Accessed 25 August 2021]

10 See https://www.pamatkovykatalog.cz/soupis/podle-relevance/1/ seznam/?druh=TSetemaSpec $=$ tem aotema $=2$-lokalizaceZahranici $=0$, [Accessed 2 September 2021]

11 STRAKOŠ, Martin (ed.) et al., 2017. Nádraži Ostrava-Vittovice. Historie | urbanismus | architektura. [OstravaVítkovice Railway Station. History | Urbanism / Architecture] Prague: NPÚ.

12 GORYCZKOVA, Nad'a (ed.), 2019 Transgas. Historie | urbanismus | architektura [Transgas. History | Urbanism / Architecture] Prague: NPÚ.

13 See www.industrialnitopografie.cz.

14 See Zikmund, J., 2020.

15 Energoprojekt, Hydroprojekt, Báňské projekty, Hutní projekt, Kovoprojekta, Projekta, Chemoprojekt, Keramoprojekt, Lignoprojekt, Potravinoprojekt, Centroprojekt, Skloprojekt.

16 See for example studies in POPELOVÁ, Lenka and ŠENBERGER, Tomáš, 2021. Prưmyslové dědictví evidence, výzkum, ochrana a nové využití. [Industrial heritage - recording, research, protection, re-use]. Prague: CTU in Prague.

17 Within the PhD programmes "Sustainable Development and Industrial Heritage" (Prof. T. Šenberger) and "Industrial Heritage" (Assoc. Prof. L. Popelová), current grants help developing typologically-oriented research both in terms of evaluation of general strategies and individual typologies, and thus individual state enterprises (glassworks, porcelain plants, telecommunication buildings, automotive industry). As a result, the inventories are continuously updated, and the definitions of specific values and possibilities for re-use of these buildings are refined.

18 The ability to draw upon developments abroad is also evident in the publication HLAVÁČEK, Emil, 1985. Architektura pohybu a proměn. [Architecture of Movement and Change]. Prague: Odeon. See POPELOVÁ, Lenka and ŠENBERGER, Tomáš, 2020 . V opuštěném industriálu jsme viděli krásu a potenciál [We Saw Beauty and Potential in the Abandoned Industrial] for more details. In: Vorlík, Petr. Rozhovory. Architektura osmdesátých let. [Interviews. Architecture of the 1980s]. Prague: FA CTU in Prague. Also, a number of articles in the press of that era document it.

19 For all examples, see Hlaváček, E., 1985.

2o See Zikmund, J., $2 \mathrm{O} 2 \mathrm{O}$.
21 For more details see POPELOVÁ, L., 2O2O. In: VORLÍK, P. Popelová, L. and Šenberger, T., 2020.

22 POPELOVÁ, Lenka, 2010. Architektonické soutěže šedesátých let 20. století publikované na stránkách periodik Architektura ČSR/ČSSR a Československý architekt. (dizertační práce) FA CTU in Prague, pp. 255 - 257. For more general information on the importance of competitions, see POPELOVÁ, Lenka, 2013. Architektonické a architektonicko-urbanistické soutěže šedesátých let. Jejich specifický přínos v dějinách československé architektury. Architektúra \& urbanizmus. 47(1-2), pp. $34-51$.

23 These references are to the competition for an architectural, technical and construction study of a Škoda service garage (published in 1967), and the architectural competition for the design of a standardised Benzina petrol station (published 1967).

24 HLAVÁČEK, Emil, 196o. Soutěž na návrh typového energobloku. Československý architekt. 6(13), p. 5.

25 In 1975, a short-list competition for the pre-plant area of AZNP Mladá Boleslav followed. 1st prize Emil Hlaváček, in cooperation with Josef Pospíšil.

26 KOVAŘíK, Emil, 1967. Vstupní část automobilových závodů v Mladé Boleslavi. Architektura ČSSR. 26(11), pp. $375-362$.

27 POPELOVÁ, Lenka and ŠPAČKOVÁ, Eva, 2014. Svět architektury a divadla. Architekt Ivo Klimeš. Prague: Grada, p. 39. Úpravna vody v Nové vsi u Frýdlantu. Československý architekt. 15(18), 1969, p. 1.

28 CAJTHAML, Miloslav, 1965 Omezená neanonymní soutěž na ústřední telekomunikační budovu v Praze - 2. fáze. Architektura ČSSR. 24(15), pp. $633-637$.

29 NOVOTNÝ, Jiří, 1968. Soutěž na řešení objektu radioreléových spojů v Praze na Strahově. [Competition for a radio transmission building in Strahov, Prague]. Architektura ČSSR. 27(9), pp. $288-292$.

30 Goryczková, N. (ed.), 2019.

31 See https://ticcih.org/wp-content/ uploads/2021/o5/Textile_mill_workshop_Lodz_2O21_June_TICCIH.pdf. [Accessed 1o September 2021]

32 See http://www.dularchitektury.cz [Accessed 20 November 2020].

33 Matěj, M. and Ryšková, M., 2018.

34 Vrabelová, R. and Goryczková, N. (eds.), at al., 2020. 